\title{
Selection and Budding Propagation of Native Bigtooth Maple for Water-conserving Landscapes
}

\author{
Melody Reed Richards ${ }^{1,2}$, Larry A. Rupp ${ }^{3,4}$, Roger Kjelgren ${ }^{3}$, \\ and V. Philip Rasmussen ${ }^{3}$
}

AdDitional index words. Acer grandidentatum, Aceraceae, budding, fall color

SumMARY. The potential of bigtooth maple (Acer grandidentatum) as a small, waterconserving landscape tree for the western United States is limited by the selection of superior accessions from a morphologically diverse gene pool and the ability to propagate wild plants in a nursery environment. Superior accessions were selected based primarily on red fall color. Aerial digital images taken during peak fall color in 2007 and 2008 were synchronized with flight global positioning system (GPS) track files using digital image editor software and visually compared with corresponding satellite images to determine the exact latitude and longitude of selected trees on the ground. Trees were physically located using GPS technology then visually evaluated for initial selection. Criteria included fall color, habitat, relative disease and insect resistance, bud quality, and plant form. From 56 observed trees of interest, six were selected for propagation. Through time-course experiments using multistemmed, bigtooth maple seedling rootstocks in a coppiced stoolbed, the optimum time for chip budding scions of wild accessions in northern Utah was determined to be July through mid-August. Further evaluation of accessions for use in the landscape industry is required.

$\mathrm{M}$ ost of the intermountain western United States between the Sierra Nevada and Rocky Mountain ranges is semiarid to arid high desert with precipitation increasing with elevation, and with cold hardiness zones of 6 or lower. Continued population growth and water demand in the face of limited water resources is forcing the adoption of water conservation, especially during periods of drought.

Plants, Soils, and Climate Department, Utah State University, 4820 Old Main Hill, Logan, UT 84322

This research was supported by the Utah Agricultural Experiment Station, Utah State University, and approved as journal paper 8456 .

This paper is a portion of a thesis submitted by Melody Richards in fulfilling a Masters Degree.

This project was supported in part by the Center for Water Efficient Landscaping, the J. Frank Schmidt Family Charitable Foundation, the Drought Management Utah project (USDA-CREES UT award 2008-34552-19042), and a Utah Department of Agriculture and Food Specialty Crop Block Grant.

We thank Xin Dai for statistical support.

Mention of a trademark, proprietary product, or vendor does not constitute a guarantee or warranty of the product by the Utah State University and does not imply its approval to the exclusion of other products or vendors that also may be suitable.

${ }^{\text {I}}$ Current address: 53 Kimberly Drive, Council Bluffs, IA 51503 .

${ }^{2}$ Former graduate student

${ }^{3}$ Professor

${ }^{4}$ Corresponding author. E-mail: Larry.Rupp@usu.edu.
Since as much as $50 \%$ to $60 \%$ of municipal water use is for urban landscaping (Kjelgren et al., 2000), landscape water conservation in the region is a high priority. Long-term conservation will require low water use landscaping (St. Hilaire et al., 2008), consisting of hardscaping, improved irrigation scheduling, and droughttolerant plants. Deciduous trees are essential functional (shade, cooling) and design elements for high desert urban landscapes, but few species are tolerant to drought, cold temperatures, and alkaline soils.

Selecting existing wild plants that are drought tolerant, both cold hardy and resistant to deacclimation (Arora and Rowland, 2011), adapted to a range of soil $\mathrm{pH}$ and alkalinity, and resistant to insects and diseases would be desirable. Aesthetic traits such as small size, unique forms, moderate growth rate, and red fall foliage (Guilford and Smith, 1959; Iles and Vold, 2003) are also highly desirable.

Native intermountain western United States deciduous tree species offer a potential pool of plants for ornamental landscape use, but assessing and selecting desirable native trees in general for landscape use is difficult, especially in remote areas. Remote sensing through photography or satellite images can be an efficient means of identifying promising populations or individual trees, particularly when assessing deciduous trees during peak fall color (Key et al., 2001) and then evaluating identified trees on the ground. True-color aerial photographs have also been shown to be a good means of mapping forest habitat (Balice, 1979).

Bigtooth maple is a native species that has combined both environmental tolerance and good landscape traits. It is native to 10 western states with a large population throughout northern Utah and southern Idaho (elevations of 4300-9200 ft). Its small size, form, and desirable fall color that make it a logical choice for use in water-conserving western landscapes (Barker, 1974, 1975; Kuhns, 2003; Tankersley and Emino, 1981) including a deciduous habit (Eastmond, 1968), temperature hardiness [ -30 to $100{ }^{\circ} \mathrm{F}$ (Kuhns, 2003)], drought tolerance (15-20 inches of annual precipitation), and adaptability to a wide range of soils and habitats. It has a wide range of forms and fall foliage colors, and while susceptible to a number or disease and insect pests, none appear debilitating enough to reduce the potential of bigtooth maples as a landscape tree (Mee et al., 2003).

Bigtooth maple is uncommon in the nursery trade and in urban landscapes. Rocky Mountain Glow ${ }^{\circledR}$ (Acer grandidentatum 'Schmidt') is the only

\begin{tabular}{llll}
\hline $\begin{array}{l}\text { Units } \\
\text { To convert U.S. to SI, } \\
\text { multiply by }\end{array}$ & U.S. unit & SI unit & $\begin{array}{l}\text { To convert SI to U.S., } \\
\text { multiply by }\end{array}$ \\
\hline 0.3048 & $\mathrm{ft}$ & $\mathrm{m}$ & 3.2808 \\
3.7854 & gal & $\mathrm{L}$ & 0.2642 \\
2.54 & inch $(\mathrm{es})$ & $\mathrm{cm}$ & 0.3937 \\
25.4 & inch $(\mathrm{es})$ & $\mathrm{mm}$ & 0.0394 \\
48.8243 & lb/1000 $\mathrm{ft}^{2}$ & $\mathrm{~kg} \cdot \mathrm{ha}^{-1}$ & 0.0205 \\
1.6093 & mile $(\mathrm{s})$ & $\mathrm{km}$ & 0.6214 \\
$\left({ }^{\circ} \mathrm{F}-32\right) \div 1.8$ & ${ }^{\circ} \mathrm{F}$ & ${ }^{\circ} \mathrm{C}$ & $\left({ }^{\circ} \mathrm{C} \times 1.8\right)+32$
\end{tabular}


cultivar readily available. It is grown on sugar maple (Acer saccharum) rootstock, produces yellow to orange-red fall color, and is commercially available (J. Frank Schmidt, Boring, OR). 'Western Torch' wasatch maple (A. grandidentatum) is an identified selection with unknown availability. Manzano ${ }^{\circledR}$ is a trademarked bigtooth maple propagated by seed from a provenance native to New Mexico.

Given the common use of native trees such as quaking aspen (Populus tremuloides) in western landscapes, it is difficult to postulate why bigtooth maple is not used more. One possibility may be that most bigtooth maple are propagated by seed and the resulting genetic diversity of color, size, and especially form make it difficult to market seedling plants as performing within known parameters. Also, with the exception of budding, vegetative propagation has been so difficult as to be commercially unfeasible (Donnelly and Yawney, 1972; Tankersley, 1981). Successful introduction of any high desert native plant into the landscape industry depends on both the ability to propagate clones into a nursery environment where they can be further evaluated (Henry and Preece, 1997) and on economical commercial propagation. The inability to propagate the tree vegetatively has limited efforts to find and develop exceptional cultivars. Such a case would be similar to other trees native to the intermountain area such as gambel oak (Quercus gambelii), which is even more difficult to propagate by vegetative means.

Vegetatively propagating bigtooth maple is challenging. It does not root well from cuttings (Tankersley, 1981), and while it does readily bud onto rootstocks, using wild scion wood is difficult (Alsup et al., 2003, Howard, 1973; Rupp et al., 2008). Certainly, using scion wood from water-stressed trees can limit budding success, which could constrain timing of bud collection within a year (Howard, 1973) and between years with varying precipitation. At this point, micropropagation also is not an option with mature trees because of the difficulty of establishing them in culture (Bowen-O'Connor et al., 2006). Budding success can be improved through chip budding that has been shown to have 3 -fold better bud-take compared with T-budding (Howard, 1973) and is simple and quick to perform (Hartmann et al., 2011).
Our objectives were to use remote sensing of fall color to identify potential cultivars for follow up assessment as commercial candidate selections and to determine optimal seasonal timing of chip budding of wild bigtooth maples in northern Utah for nursery establishment.

\section{Materials and methods Tree Selection}

Wild bigtooth maple specimens were selected by evaluating fall color, overall aesthetics, and functional characteristics. An initial assessment of aesthetics and fall color was accomplished by taking aerial digital photos of diverse bigtooth maple populations in Cache Valley, UT, and then visually identifying exceptional specimens from each image based on fall color and form. Additional trees were also located via communication with plantsmen familiar with the area (J. Morris, personal communication).

In 2007, true-color aerial photographs were taken free hand on 11 Sept. using a digital camera (D40; Nikon ${ }^{\circledR}$, Melville, NY). In 2008, freehand truecolor digital images were taken on 30 Sept. and 2 Oct. with Nikon ${ }^{\circledR}$ D60 or D40 cameras $(18-55 \mathrm{~mm}$ lens). About 200 pictures were taken on each flight. Flight transects included the Wellsville and Bear River Mountain ranges in Cache Valley, UT (about lat. $41.41^{\circ} \mathrm{N}$ to $42.33^{\circ} \mathrm{N}$, long. $111.57^{\circ} \mathrm{W}$ to $\left.112.10^{\circ} \mathrm{W}\right)$.

The freehand images taken in 2007 were very difficult to locate on the ground. Therefore, in 2008, tracking data from a handheld GPS device (GPSMAP ${ }^{\circledR} 60 \mathrm{C}$ or GPSMAP ${ }^{\circledR} 60 \mathrm{CS} \mathrm{x}$; Garmin ${ }^{\circledR}$ International, Olathe, KS) were synchronized with digital image time using digital image editor software [GeoSetter $\odot$ (Schmidt, 2008)] to record the geographic coordinates of the airplane at the time each image was taken. The exact latitude and longitude of trees selected for further evaluation was determined by using the image editor software coordinates to narrow the location of the selected image and then visually comparing the digital images with similar images on Google $^{\circledR}$ Earth (Google, Mountain View, CA). Selected trees were located in July to mid-August in 2008 and 2009 using Google ${ }^{\circledR}$ Earth images and a Garmin ${ }^{\circledR}$ GPSMAP 60CSx. Each tree was visited and visually evaluated for landscape potential and budwood collected for propagation. Round and pyramidal forms were considered aesthetically acceptable. Those with nonuniform branching were considered aesthetically unacceptable. Unique forms, such as columnar, were noted for further evaluation.

Those trees found visually acceptable were further assessed by photographing the tree from the cardinal directions using a digital camera (Powershot $^{\circledR}$ SD750 Digital ELPH; Canon ${ }^{\circledR}$ USA, Lake Success, NY) to document the overall tree form. Images of the leaves, trunk(s), buds, and fruit were also recorded. More objective criteria were also examined based on U.S. Department of Agriculture, Agricultural Research Service (USDAARS) Germplasm Resources Information Network (USDA-ARS, 2008) criteria and included habitat, foliar disease, insect damage, budwood quality, self-layering tendency, leaf length and width, tree height and crown width, trunk circumference, and fruit length and width (Dana, 2000). Minimum acceptable budwood quality was two graftable buds per shoot. Trees with multiple stems were considered less desirable than those with fewer stems or a single leader.

Tree characteristics were documented by measuring averagesized leaves and fruit, and measuring tree height, average crown width, and trunk(s) circumference at $4 \mathrm{ft}$ aboveground.

Fall leaf color was documented in late September and early October (2008 or 2009) by taking pictures with a digital camera (Powershot ${ }^{\circledR}$ SD750 Digital ELPH). A Munsell ${ }^{\circledR}$ color chart (ColorAccuracy, North Brunswick, NJ) was included in each picture to accurately document the color of the trees (data not shown). Leaf samples were also collected and pressed for color comparison.

While not a formal experiment, an attempt was made to propagate all selected wild accessions to a nursery environment in July and August of 2008 and 2009. Nine to 17 budsticks were collected from each tree and budded to coppiced seedling rootstocks. Buds from each accession were budded onto multiple, separate stems of a single rootstock. Budding was done within $24 \mathrm{~h}$ of excising the budwood from the selected, wild tree, but usually within 2 to $3 \mathrm{~h}$ of collection. Final assessments of bud-take 
were made in Spring 2009 and 2010 based on actual budbreak. A repeated budding attempt for USU-ACGR1041 was done in Summer 2010 by a different individual.

\section{Optimization of Chip Budding Timing}

A series of four experiments were conducted to determine the optimum date for chip budding of bigtooth maple in northern Utah. Expts. 1-3 used a block of coppiced, multiplestemmed, seed-propagated bigtooth maple trees established in 1999 at the Utah State University Greenville Research Farm (North Logan, UT; lat. $41.765768^{\circ} \mathrm{N}$, long. $111.813040^{\circ} \mathrm{W}$; Millville silt loam soil) as rootstocks. Trees were pruned back to the crown every year (starting in 2001) to induce vigorous shoot growth. Ammonium sulfate $21 \mathrm{~N}-0 \mathrm{P}-0 \mathrm{~K}$ fertilizer $\left(0.5 \mathrm{lb} / 1000 \mathrm{ft}^{2}\right.$ nitrogen $)$ was applied to the block annually, starting in 2004. Overhead irrigation was applied twice daily for $10 \mathrm{~min}$ from July to mid-September each year and the block was mulched with conifer wood shavings. Expt. 4 used container-grown bigtooth maple seedlings as the rootstock.

All budwood was bigtooth maple and was collected and budded on the same day, generally within the morning hours. Successful bud-take was based on bud growth the following spring. Results of all experiments were analyzed using logistic regression tests of occurrence with Statistix $9^{\odot}$ (Analytical Software, Tallahassee, FL). Differences in least square means were completed in $\mathrm{SAS}^{\circledR}$ (version 9.2; SAS Institute, Cary, NC) using the GENMOD procedure.

Expт. 1, 2006. The goal of the initial experiment was to minimize the effect of budding technique while determining the optimum time for successful budding. The experiment was conducted on 15 coppiced stock plants, each with enough shoots that a different one could be used for each bud date (weekly from 21 June to 6 Sept.). Because the shoots were growing and changing over the season, budding locations were not randomly determined, but based on selecting the best shoot per stock plant at the time of budding. Budding was done by removing a chip bud at the second node from the base of a rootstock shoot and replacing it in its original location, thus insuring a perfect mechanical fit. Subtending leaves were removed from the excised bud and the bud opposite on the shoot. Buds were tied with parafilm ${ }^{\circledR}$ (Pechiney Plastic Packaging, Chicago, IL) tape covering the entire bud and all wounded surfaces. The tape was removed after $\approx 3$ weeks and budding success determined by budbreak the following spring.

ExpT. 2, 2007. In 2007, an experiment was conducted to determine the effect of budding date on budding success with scion wood collected from a wild bigtooth maple and budded onto coppiced seedling rootstock as before. Budwood was collected from bigtooth maple tree USU-ACGR-1009 in Smithfield Canyon, UT, in the Uinta-Wasatch-Cache National Forest (lat. 41.874874 ${ }^{\circ} \mathrm{N}$, long. $\left.111.750161^{\circ} \mathrm{W}\right)$. USU-ACGR1009 is located at $6500 \mathrm{ft}$ elevation on a southeast-facing dry slope. This bigtooth maple was selected for bright red fall color and round-pyramidal form.

Budwood (terminal shoots of current season with one or more sets of lateral buds and a terminal bud) was collected in the morning, on five dates (15 June, 2 July, 16 July, 30 July, and 13 Aug. 2007). Both budwood and shoots within rootstocks were not selected randomly, but were chosen based on the budwood meeting the stated criteria, and stock shoots being of optimum size to match the bud. The budwood was cut basipetally to the bud scar of 2-year-old wood to avoid damaging the bud and budstick. The terminal bud had set and was not actively growing on any of the budsticks. Budwood was cut or broken off the tree, leaves were stripped, and budwood was then sealed in a plastic freezer bag with a moist paper towel and placed in a cooler with ice. The grafting of the buds occurred within 2 to $3 \mathrm{~h}$ after collection.

All rootstocks were vigorously growing in response to pruning and had not set terminal buds. The most vigorous of the wild budwood was selected for budding and one bud was chip budded onto one shoot per rootstock plant per date. Buds were placed above the first or second node from the base of the rootstock, except for those budded on 30 July 2007 , which were inadvertently placed between the second and third nodes.
Parafilm grafting tape was used to cover the entire bud, left for $\approx 6$ weeks, and then removed. The above budding process was repeated every 2 weeks with buds placed on different shoots within the same plant. Buds were examined on 13 May 2008 and scored as either alive or dead based on bud development.

ExpT. 3: 2009. In 2009, Expt. 2 was repeated using randomized selection of rootstock shoots and budwood. Twelve coppiced rootstock plants at Greenville Research Farm were chosen, and five shoots of moderate vigor and uniformity selected within rootstocks. Rootstock shoots were randomly assigned one of five budding dates (22 June, 6 July, 20 July, 3 Aug., and 17 Aug.). At the time of budding, all rootstock shoots had active terminal buds, while terminal buds had set on all scion wood. Budwood (terminal shoots of current season with one or more sets of lateral buds and a terminal bud) was collected from USU-ACGR-1009. Budwood was collected in the morning, leaf blades were removed from it, and then it was sealed in a plastic freezer bag and kept cool until budded $\approx 2$ to 3 h later. Ninety-six shoots (budsticks) with at least two nodes with buds of the required minimum size (full, mature buds on a wide enough stem to permit cutting the stem without damaging the bud) were selected before the experiment. Sixteen budsticks were randomly assigned to each budding date and labeled. At the assigned date, budsticks were collected, grouped, and the most vigorous and most basipetal 12 buds from those budsticks were selected for budding. Each of the 12 budsticks was randomly assigned to a rootstock. The four remaining budsticks were used as replacements for failed attempts or discarded.

Budding was done by first removing a chip from an internode of the rootstock shoot with a budding knife. This was done by making a $45^{\circ}$ angle cut to a depth about equivalent to one-third the diameter of the budstick, and then making another incision proceeding linearly from a point $\approx 2-3 \mathrm{~cm}$ above the bud to the base of the first cut. The position of the internode used varied to insure that the internode was the same diameter or slightly larger than the budstick to insure the best possible fit. Next, scion 
buds were excised by making a similar $45^{\circ}$ angle cut $\approx 1 \mathrm{~cm}$ below the bud to a depth one-third the diameter of the stem, and then making another incision proceeding linearly from a point $\approx 1 \mathrm{~cm}$ above the bud to the base of the first cut. The base of each petiole was left in place to help protect the bud and the entire bud and shield was wrapped with tape to tie the buds in place. The tape was slit on the opposite side of the bud after 3 weeks if the tape had not split on its own. Rootstocks were pruned in Apr. 2010 by cutting $1 \mathrm{~cm}$ above the top of the bud shield. Buds were examined on 10 May 2010 and scored as either alive or dead based on their development.

Expt. 4. 2009. Optimum budding date was further evaluated using containerized seedling bigtooth maples as rootstocks, a different scion, and a different person doing the budding. Rootstocks were 2 -year-old bigtooth maple seedlings planted in 2-gal pots, grown under $30 \%$ shade, and irrigated twice daily for $20 \mathrm{~min}$ the Greenville Research Farm.

Budwood was collected from a selected wild bigtooth maple specimen in Mantua, UT (USU-ACGR-1022; lat. $41.50242^{\circ} \mathrm{N}$, long. $\left.111.95759^{\circ} \mathrm{W}\right)$ on 23 June, 7 July, 21 July, 4 Aug., and 18 Aug. Eighty budsticks from the main canopy, chest height or higher, were previously selected and marked with tape. Subsequently, 16 budsticks were randomly selected on each date. Twelve seedling shoots were then randomly selected for the 12 randomly selected budsticks for budding. Chip budding was completed as previously described. Budding occurred within $24 \mathrm{~h}$ of excising the budwood. A final assessment of budding success was made in Spring 2010 based on actual budbreak.

\section{Results \\ Tree Selection}

None of the trees identified in images from Fall 2007 were selected for further evaluation. However, during ground visits to those trees, two previously unidentified trees (USUACGR-1022 and-1032) in the near vicinity were selected. A third tree (USU-ACGR-1034) was also selected in Summer 2008 through on-ground observation unrelated to aerial photographs (J. Morris, personal communication). Evaluation of the images taken in Fall 2008, coupled with GPS data and digital image editor software, was more effective than previous images taken in 2007. Based initially on red color, a total of 15 bigtooth maple trees were selected from the 2008 photographs for further evaluation. On-ground evaluation of those trees in the Summer 2009 resulted in three additional trees (USU-ACGR-1036, 1038, and 1041) being selected for further production and evaluation. An example of the perspective offered by aerial photography (Fig. 1) and subsequent ground image (Fig. 2) for USU-ACGR-1036 are shown.

Six trees were selected for further evaluation (Table 1). Tree 1022 was found at an elevation of $5570 \mathrm{ft}$ on a dry, south-facing slope. It had a uniform red fall color, a round canopy form with multiple leaders, and measured $18 \mathrm{ft}$ tall by $17 \mathrm{ft}$ wide. Tree 1032 was found at a similar elevation, but on a northeast facing slope near the top of a ridge. Its fall color was more reddish-orange and it had a distinct columnar form with multiple leaders. The tree measured $35 \mathrm{ft}$ tall and had a crown width of $12 \mathrm{ft}$. Tree 1034 had a strong central leader with a height of $58 \mathrm{ft}$ and crown width of $26 \mathrm{ft}$. This tree occurred in a dense grove of trees on a north-facing slope. This tree was selected primarily for its strong central leader and tree form. Its fall color was a mix of greens, reds, yellows, and oranges that was difficult to evaluate because of the height of

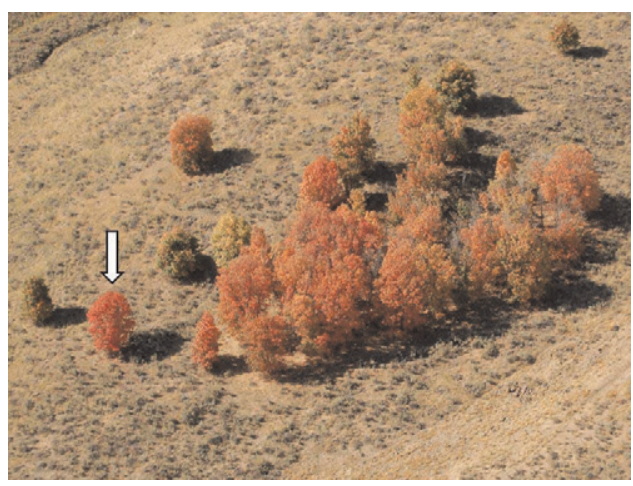

Fig. 1. Aerial photograph of bigtooth maple trees taken 29 Sept. 2008 with selected tree USU-ACGR-1036 indicated by arrow.

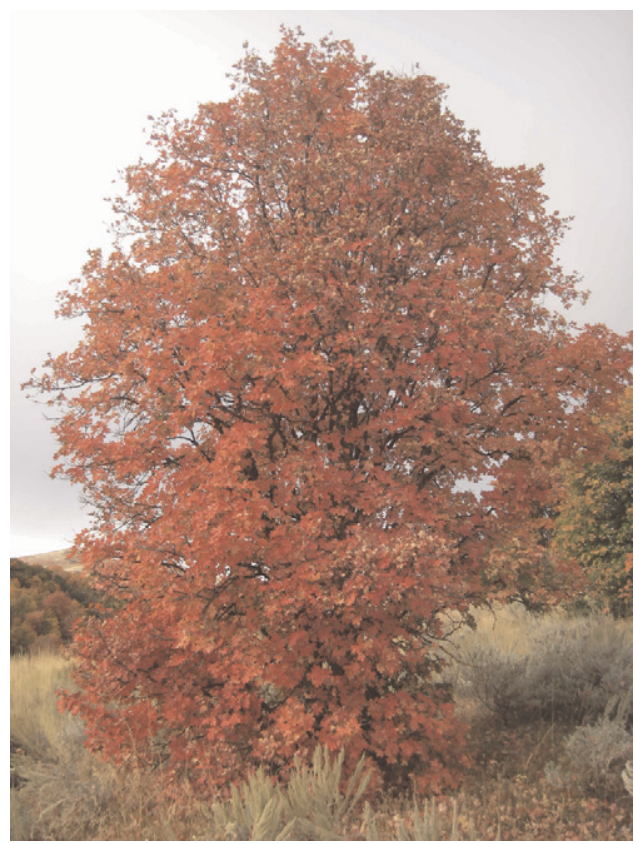

Fig. 2. Ground photograph of selected bigtooth maple tree USU-ACGR-1036 taken 29 Sept. 2009. 


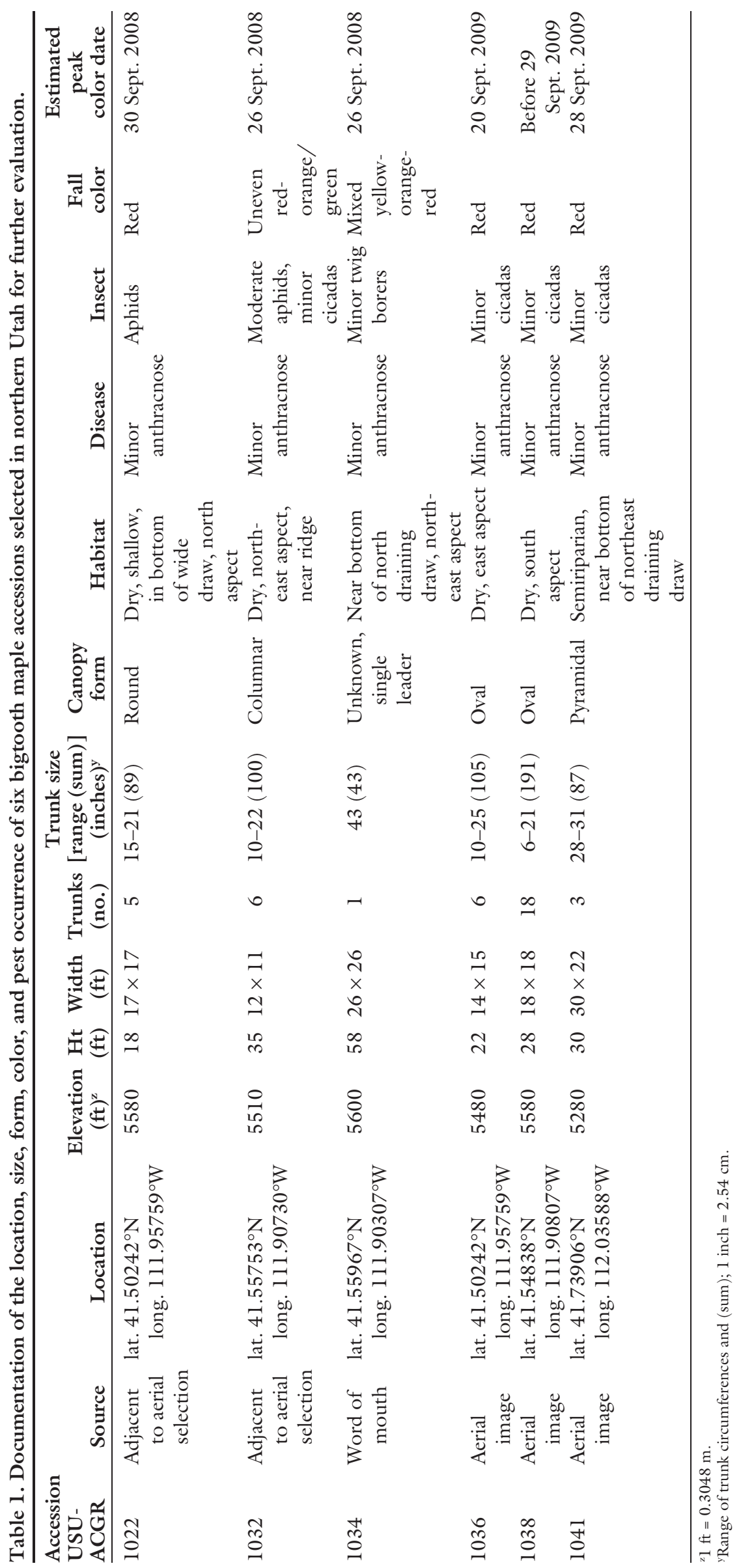

the tree and its blending with the canopies of adjacent trees. Tree 1036 was located close to tree 1032 , but on a more easterly facing slope in a dry area (not riparian). The tree had a uniform red color and an oval form with a height of $22 \mathrm{ft}$ and the width averaging $15 \mathrm{ft}$. It also had multiple leaders. Tree 1038 was also located within a 0.5 mile of trees 1032 and 1034 on an easterly aspect. It had a uniform red fall color, oval form, and a height of $28 \mathrm{ft}$ and a width of $18 \mathrm{ft}$. It had a large number of leaders yet they blended into a nice form. The final tree (1041) was located well north of the other selections and had a much more pyramidal form. The color was also uniformly red and the crown measured $30 \mathrm{ft}$ tall. The width of the crown at two measurements was more irregular than the other trees at 22 and $30 \mathrm{ft}$. This tree was located in a semiriparian location near the bottom of a dry ravine that drained to the northeast.

Final assessments of the informal effort to propagate from this group of potentially superior trees were made in Spring 2009 and 2010 based on actual budbreak. Budding success ranged from $0 \%$ to $56 \%$ (Table 2). Since USU-ACGR-1041 had no successful bud-take, it was budded again in 2010 resulting in $62 \%$ success.

\section{Optimization of Chip Budding}

EXPT 1: 2006. The 2006 experiment on return budding showed a budding success of $53 \%$ to $88 \%$ between 28 June and 9 Aug. Success rates on 21 June $(48 \%)$ and 16 Aug. and later $(28 \%$ or less) were noticeably less (Fig. 3A). Data analysis supports the conclusion that 28 June to 9 Aug. was an acceptable window for successful budding.

Budding success decreased as buds were applied later in the season. However, this experiment did not determine if decreased success was due to seasonal timing or decreased quality of available rootstocks and budwood (Fig. 3A).

ExPT. 2: 2007. The 2007 experiment using wild budwood and coppiced seedling rootstock indicated that highest bud-take success occurred at the end of July (30 July 2007). The results showed mid-June an ineffective time for successful budtake, with a wider window of successful bud-take from early July to 
Table 2. The relative success of chip budding as a means of propagating six wild bigtooth maple accessions in a coppiced nursery environment.

\begin{tabular}{lccc}
\hline Accession & Buds attempted (no.) & Success (\%) & Date budded \\
\hline USU-ACGR-1022 & 9 & 56 & 10 July 2008 \\
USU-ACGR-1032 & 17 & 53 & 8 Aug. 2008 \\
USU-ACGR-1034 & 15 & 27 & 11 Aug. 2008 \\
USU-ACGR-1036 & 10 & 40 & 16 July 2009 \\
USU-ACGR-1038 & 12 & 8 & 22 July 2009 \\
USU-ACGR-1041 & 12 & 0 & 28 July 2009 \\
USU-ACGR-1041 & 13 & 62 & 31 July 2010 \\
Avg & $\mathbf{1 2 . 6}$ & $\mathbf{3 5 . 1}$ & \\
\hline
\end{tabular}

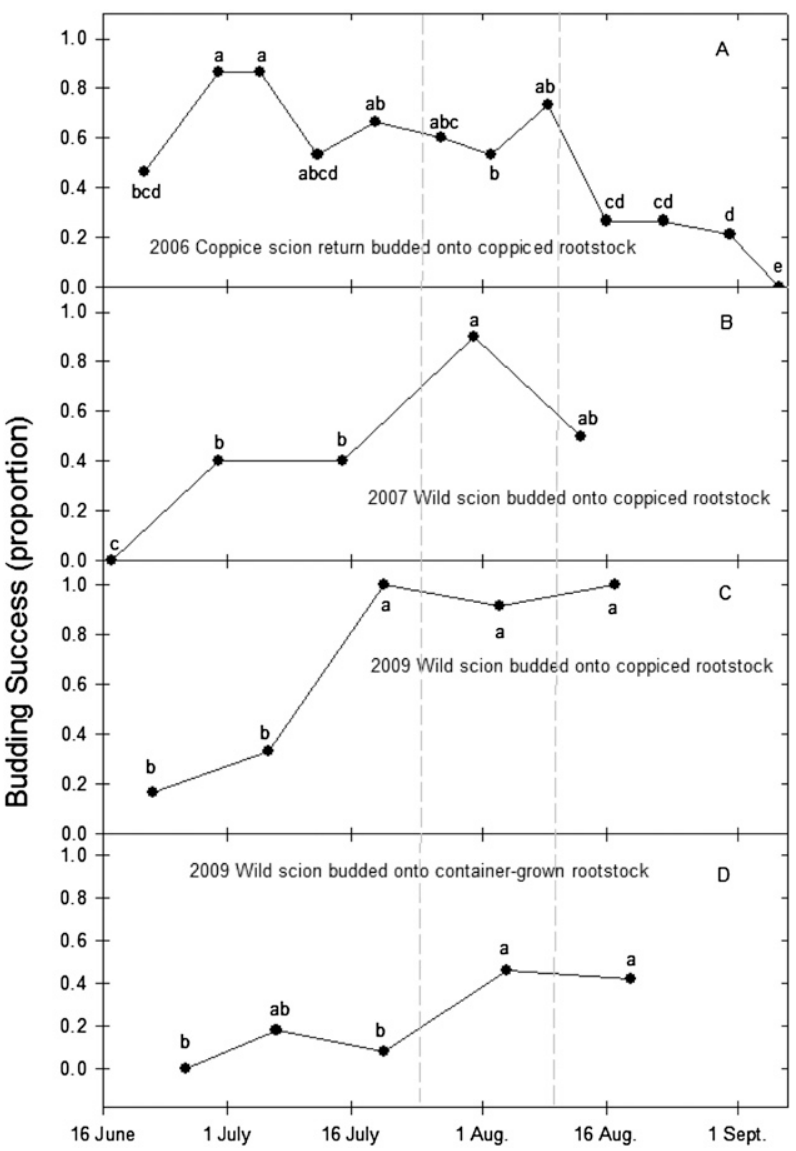

Fig. 3. The effect of chip budding dates over four production/budding conditions on bigtooth maple in northern Utah showing optimum budding from late July to early August. The effects of (A) 2006 budding dates with "return buds," (B) 2007 budding dates with wild scion USU-ACGR-1009 on coppiced seedling rootstocks, (C) 2009 budding dates with wild scion USU-ACGR-1009 on coppiced rootstocks, and (D) 2009 budding dates with wild scion USU-ACGR-1022) on containerized 2-year-old bigtooth maple rootstock. Statistical analysis showed the overall effect of date to be statistically significant for (A and C) $P<0.0001$, (B) $P=$ 0.045 , and (D) $P=0.0077$ based on logistic regression tests of occurrence with Statistix $9^{\odot}$ (Analytical Software, Tallahassee, FL). Means with the same letter within graphs are not significantly different according to the SAS ${ }^{\circledR}$ GENMOD procedure (version 9.2; SAS $^{\circledR}$ Institute, Cary, NC).

mid-August (30 June, 15 July, and 13 Aug. 2007). Overall, $45 \%$ of the buds were successful (59\% for July 2007). The effect of budding date on budding success with wild budwood was statistically significant $(P<0.045)$. Budding success was lower on 15 June 2007 than all other dates. The highest bud-take was on 30 July 2007. No difference occurred between 2 July,
16 July, and 13 Aug. 2007 (Fig. 3B). This experiment also had the potential to confound budding time with quality of available plant material.

Expт. 3: 2009. Results of the 2009 experiment using wild scions and coppiced rootstocks $(n=12)$ showed reduced bud-take for earlier budding dates of 22 June (17\%) and 6 July 2009 (33\%). Success increased dramatically for buds grafted after mid-July through mid-August (20 July, 3 Aug. and 17 Aug. 2009) (Fig. 3C), with rates over $90 \%$. The effect of budding date on budding success with wild bigtooth maple scions was significant $(P<0.0001)$. The data indicated no differences within the first two dates or the last three, but the first two dates were different from the last three. Mid-July through mid-August appears to be the optimal time for budding wild budwood in 2009 . These data verified that budding before the very end of June was not successful. The experiment was not continued past 17 Aug., so the latest viable date for successful budding was not determined. However, in the 2006 return budding experiment, success was reduced to less than $30 \%$ in the latter half of August and the final budding date of 6 Sept. was not successful (Fig. 3A).

EXPT. 4: 2009. The results of budding on 2-year-old containerized plants indicated that 4 Aug. 2009 was the optimum date with $46 \%$ success, followed by 19 Aug. 2009 with 42\% success. There was $0 \%$ success on 23 June 2009 and overall bud-take averaged 23\% (Fig. 3D). The effect of budding date on budding success with wild budwood on containerized plants was significant $(P=0.0077)$ in 2009.

\section{Discussion}

Several effective ways may be used to select native trees with landscaping potential. Word of mouth from individuals familiar with the desired plant and its wild populations is obviously a very effective means of selection. Aerial photography can also be effective, especially when selecting for a highly visible trait such as red fall color. It is interesting to note that while some aerially selected trees were unacceptable, there were often better trees in the immediate vicinity that were overlooked from the air. Possible reasons for failure to document such 
trees from the air include different timing of fall color onset (the incipient color to final leaf drop of bigtooth maple forests in northern Utah covers a period of about 6 weeks) or location in a copse such that individual trees become difficult to differentiate. Rather than being a negative aspect of aerial selection, this suggests aerial photography might also be used as a means of narrowing down the search area, rather than finding specific trees. Most importantly, desirable trees for further research were identified.

Further work is required to determine the capacity of the trees selected in this study for commercial propagation and production, as well as performance in constructed landscapes. For example, it is unknown if daughter plants of multiple-stemmed mother trees are amenable to production as small, single leader shade trees. Bigtooth maple naturally propagates itself by layering of the lower branches, which can result in multiple stems or trunks in a genetically uniform copse with none being particularly tree-form. However, if such trees were pruned to eliminate the ability to naturally layer, they may easily retain a desirable tree form.

Propagation of native trees by budding has proven challenging because of lack of control over scion material. For example, it is not uncommon for bigtooth maple in a nursery environment to have active terminal bud growth through July resulting in shoots with 10 or more nodes. However, wild trees typically set bud in late June to early July and may only have two to three nodes per shoot. Wild growth is typically much smaller in diameter than nursery-grown plants and is likely to be more water stressed as well. These characteristics may have contributed to the variable $(0 \%$ to $56 \%)$ success in budding the six selections in 2009. All of the trees selected were eventually successfully budded.

Another potential challenge to budding native trees in Utah is the availability of optimally growing rootstock material. Rootstock vigor, health, and timing are critical to successful budding (Hartmann et al., 2011), and nurseries producing rootstocks for budding optimize plant material for that purpose. In contrast, native plant nurseries may use a target plant concept with very different goals
(Landis, 2008). Use of vigorously growing coppiced rootstocks can provide an easily managed source of rootstock material that, while not lending itself to nursery stock production, does allow an effective means of collecting wild materials and establishing them in a nursery environment. Our results suggest that rootstocks grown in containers under our conditions may not be as easy to bud as the coppiced materials.

Some buds could have been damaged in Expt. 2 during the removal of the grafting tape. In Expt. 3 , leaf petioles were cut off just above the bud and then left attached to the bud shield. It is possible that leaving the petiole may provide needed protection to the bud from the tape when completely covering the bud.

This research shows that a reasonable window of opportunity exists for successful budding of wild bigtooth maples in northern Utah. During the 2009 budding season, this window was from mid-July to the middle of August. While the data from 2006 and 2007 are derived from selecting the best buds and shoots at each budding date and do not account for possible changes in quality over time, they do support the results from 2009. However, the conclusion that mid-July to mid-August is the optimum time for budding wild bigtooth maples in northern Utah may not translate directly to budding with nursery-grown budwood. In our experience, such budwood typically grows longer before setting a terminal bud, and the stem diameters are much larger relative to the size of the bud than with wild budwood. Budding is an effective means of establishing wild trees in a nursery environment, but more sustainable means of commercial propagation in the relatively short-season, cold-desert climate of Utah may exist.

Utah does not have a large nursery industry and limited expertise exists in the production areas of grafting and budding. While production of native plants (which may not be adapted to production in states with larger nursery industries) by local growers is encouraged, it may be economically daunting to establish the production capability required for production of budded trees.

\section{Literature cited}

Arora, R. and L.J. Rowland. 2011. Physiological research on winter-hardiness: Deacclimation resistance, reacclimation ability, photoprotection strategies, and a cold acclimation protocol design. HortScience 48:1070-1078.

Alsup, C., M.J.C. Cole, and L. Claypool. 2003. Timing and IBA application affect rooting of Acer saccharum Marsh. stem tip cuttings. J. Prop. Ornamental Plants $3: 42-46$.

Balice, R.G. 1979. Mapping forest habitat types in the Uinta Mountains, Utah, utilizing natural color and color infrared photography. Amer. Soc. Photogrammetry: Seventh Biennial Workshop on Color Aerial Photography in the Plant Sciences and Related Fields. Falls Church, VA. p. 101-109.

Barker, P. 1974. The spectacular canyon maple. Utah Sci. 35:7-10.

Barker, P. 1975. Acer grandidentatum and its propagation. Intl. Plant Prop. Soc. Combined Proc. 25:33-38.

Bowen-O'Connor, C., J. Hubstenberger, C. Killough, D.M. VanLeeuwen, and R. St. Hilaire. 2006. In vitro propagation of Acer grandidentatum Nutt. In Vitro Cell. Dev. Biol. Plant 43:40-50.

Dana, M.N. 2000. Landscape tree appraisal. 9 Mar. 2010. <http://www.hort. purdue.edu/hort/ext/Pubs/HO/HO\% 5F201.pdf>.

Donnelly, J.R. and H.W. Yawney. 1972. Some factors associated with vegetatively propagating sugar maples by stem cuttings. Intl. Plant Prop. Soc. Combined Proc. 22:413-430.

Eastmond, R.J. 1968. Vegetational changes in the mountain brush community of Utah during eighteen years. Brigham Young Univ., Provo, UT, MS Thesis.

Guilford, J.P. and P.C. Smith. 1959. A system of color-preferences. Amer. J. Psychol. 72:487-502.

Hartmann, H.T., D.E. Kester, F.T. Davies, Jr., and R.L. Geneve. 2011. Hartmann and Kester's plant propagation: Principles and practices. 8th ed. Prentice Hall, Englewood Cliffs, NJ.

Henry, P.H. and J.E. Preece. 1997. Production and rooting of shoots generated from dormant stem sections of maple species. HortScience 32:1274-1275.

Howard, B.H. 1973. Research into budding Acers and other difficult subjects. Intl. Plant Prop. Soc. Combined Proc. 23:193-194. 


\section{Research Reports}

Iles, J.K. and A.M. Vold. 2003. Landscape tree cultivar preferences in Iowa. U.S.A. J. Arboriculture 29:331-336.

Key, T., T.A. Warner, J.B. McGraw, and M.A. Fajvan. 2001. A comparison of multispectral and multitemporal information in high spatial resolution imagery for classification of individual tree species in a temperate hardwood forest. Remote Sens. Environ. 75:100-112.

Kjelgren, R.K., L. Rupp, and D. Kilgren. 2000. Water conservation in urban landscapes. HortScience 35:1037-1040.

Kuhns, M. 2003. Canyon maple: A tree for the interior west. 14 Jan. 2012. <http:// forestry.usu.edu/htm/city-and-town/ tree-selection/canyon-maple-a-tree-forthe-interior-west>.
Landis, T.D. 2008. The target plant concept, p. 15-31. In: R.K. Dumroese, T. Luna, and T.D. Landis (eds.). Nursery manual for native plants: A guide for tribal nurseries. Vol. 1. Nursery management. U.S. Dept. Agr. For. Serv., Agr. Hdbkl. 730 .

Mee, W., J. Barnes, R. Kjelgren, T. Sutton, T. Cerny, and C. Johnson. 2003. Water wise: Native plants for intermountain landscapes. Utah State Univ. Press, Logan, UT.

Rupp, L.A., M. Reed, W. Varga, and P. Rasmussen. 2008. Collecting Acer grandidentatum clones in northern Utah: An overview. Intl. Plant Prop. Soc. Combined Proc. 58:379-380. (abstr.).

Schmidt, F. 2008. GeoSetter. 14 Jan. 2012. <http://www.geosetter.de/en/>.
St. Hilaire, R., M.A. Arnold, D.C. Wilkerson, D.A. Devitt, B.H. Hurd, B.J. Lesikar, V.I. Lohr, C.A. Martin, G.V. McDonald, R.L. Morris, D.R. Pittenger, D.A. Shaw, and D.F. Zoldoske. 2008. Efficient water use in residential urban landscapes. HortScience 43:20812092.

Tankersley, B.E. 1981. Growth and propagation of Acer grandidentatum Nutt. Texas A\&M Univ., College Station, TX, MS Thesis.

Tankersley, B.E. and E.R. Emino. 1981. Propagation of Acer grandidentatum Nutt by layering. Intl. Plant Prop. Soc. Combined Proc. 31:512-515.

U.S. Department of Agriculture. 2008. Germplasm Resources Information Network. Descriptors for WOODYLANDSCAPE. 14 Jan. 2012. <http:// www.ars-grin.gov/cgi-bin/npgs/html/ desclist.pl?211>. 